\title{
PERAN KECERDASAN EMOSIONAL DAN DUKUNGAN SOSIAL TERHADAP PENYESUAIAN DIRI MAHASISWA BARU UNIVERSITAS UDAYANA YANG BERASAL DARI LUAR PULAU BALI Ida Ayu Gede Kusumaastuti Widihapsari dan Luh Kadek Pande Ary Susilawati Program Studi Psikologi, Fakultas Kedokteran, Universitas Udayana idaayu.kusumaastuti@gmail.com
}

\begin{abstract}
Abstrak
Mahasiswa baru yang memutuskan untuk menjalani perkuliahan di luar daerah asalnya sebagian besar akan mengalami tekanan akibat lingkungan perkuliahan yang berbeda dengan masa SMA, serta adanya perbedaan norma, budaya dan kebiasaan dengan daerah asalnya. Mahasiswa baru yang merantau perlu menyesuaikan diri dengan lingkungan perkuliahan dan kebudayaan setempat untuk mengurangi tekanan yang dirasakan agar proses perkuliahan berjalan dengan baik dan dapat mencapai prestasi akademik yang diinginkan. Kecerdasan emosional yang terdiri dari kemampuan untuk memahami dan mengelola emosi diri, memahami emosi orang lain, memotivasi diri dan menjalin hubungan yang baik dengan orang lain dinyatakan dapat membantu individu dalam mengatasi tekanan yang dihadapi, sehingga dapat mempermudah proses penyesuaian diri. Taraf dukungan sosial yang tinggi juga dapat meningkatkan kemampuan individu untuk menyesuaikan diri. Dukungan sosial dapat berasal dari keluarga, teman sebaya, maupun staf pengajar di kampus. Penelitian ini bertujuan untuk mengetahui peran kecerdasan emosional dan dukungan sosial terhadap penyesuaian diri mahasiswa baru Universitas Udayana yang berasal dari luar Pulau Bali. Subjek dalam penelitian ini adalah 112 orang mahasiswa Universitas Udayana yang berasal dari luar Bali dan tidak sedang tinggal dengan keluarga atau saudara, yang dipilih dengan menggunakan teknik simple random sampling. Instrumen dalam penelitian ini adalah skala penyesuaian diri, skala kecerdasan emosional dan skala dukungan sosial. Hipotesis penelitian diuji dengan teknik analisis regresi berganda. Hasil analisis regresi berganda menunjukkan nilai signifikansi sebesar 0,000 $(\mathrm{p}<0,05)$ sehingga dapat disimpulkan kecerdasan emosional dan dukungan sosial secara bersama-sama berperan terhadap penyesuaian diri.
\end{abstract}

Kata kunci: penyesuaian diri, kecerdasan emosional, dukungan sosial

\begin{abstract}
The first year students from outside Bali would be under pressure because there were differences between norms and culture in college's environment and their origin environment. The first year migrant students have to adjust to the local environment and college's culture so the lecture went well and the students can achieve the academic achievement. Emotional intelligence can help individuals to cope with the pressures, and can facilitate the process of adjustment. Emotional intelligence consists of the ability to understand and manage emotions, ability to understand the emotions of others, ability to self-motivated and have a good relationship with others. A high level of social support also can increase an individual's ability to adapt. Social support can come from family, peers, and other senior students. The purpose of this study was to determine the role of emotional intelligence and social support toward adjustment among Udayana University's first year migrant students from outside of Bali. Subjects in this study were 112 Udayana University's first year migrant students who come from outside of Bali and not living with family. The subjects were selected using simple random sampling technique. Instruments in this study were the adjustment scale, emotional intelligence scale and social support scale. The hypothesis was tested by the analysis of multiple regression techniques. The results of multiple regression analysis showed a significance value of $0.000(\mathrm{p}<0.05)$ so it can be concluded that emotional intelligence and social support contributed to the adjustment.
\end{abstract}

Keywords: adjustment, emotional intelligence, social support 


\section{LATAR BELAKANG}

Pendidikan dan sekolah merupakan hal yang penting dalam hidup manusia, karena sekolah merupakan pengalaman utama organisasi dalam hidup. Sekolah dapat menawarkan kesempatan untuk mempelajari berbagai informasi, mempertajam keterampilan lama dan menguasai keterampilan baru, serta memperluas wawasan intelektual dan sosial individu. Sekolah juga memberikan lingkungan sosial berupa kawan-kawan sebaya, kawan-kawan lain, serta kelompok yang dapat memberikan pengaruh yang kuat bagi perkembangan individu (Papalia, Olds, \& Feldman, 2008).

Dewasa ini, individu dapat mengenyam pendidikan sejak usia dini, dan berlanjut hingga masa dewasa. Pendidikan yang diikuti oleh individu berjalan sesuai dengan tahap perkembangan, dan akan mengalami transisi dari satu tingkat pendidikan ke tingkat berikutnya. Salah satu transisi yang dialami oleh sebagian besar individu adalah transisi dari Sekolah Menengah Atas (SMA) menuju perguruan tinggi (Santrock, 2007). Individu pada fase ini akan menyandang status sebagai mahasiswa baru. Menurut Tim Penyusun Kamus Pusat Bahasa (2008), mahasiswa dapat didefinisikan sebagai seseorang yang belajar di perguruan tinggi, sedangkan mahasiswa baru tidak hanya berarti siswa atau mahasiswa tahun pertama di perguruan tinggi, namun juga orang baru atau pemula (Santrock, 2007). Mahasiswa baru umumnya berada dalam fase remaja akhir, yaitu dalam rentang usia 17 sampai 22 tahun.

Masa remaja akhir ditandai dengan kemampuan untuk bertanggung jawab pada diri sendiri dan mengambil keputusan secara mandiri, serta merupakan periode penyesuaian diri dan pengintegrasian perubahan masa remaja awal yang lebih stabil (Santrock, 2007).

Selama periode ini remaja berusaha memantapkan tujuan hidup yang telah ditetapkan dan mengembangkan sense of personal identity, salah satunya dilakukan dengan memasuki perguruan tinggi yang sesuai dengan minat dan kemampuannya (Agustiani, 2009). Pengalaman bersekolah pada fase ini tidak semata-mata merupakan kesempatan untuk menemukan identitas diri, tetapi dapat menjadi halangan dalam perjalanan menuju kedewasaan karena terdapat banyak perubahan atau transisi yang akan dialami oleh remaja akhir (Papalia, dkk, 2008).

Bagi sebagian remaja akhir yang berstatus sebagai mahasiswa baru, bentuk transisi yang dialami dari masa SMA menuju perguruan tinggi melibatkan peralihan atau perubahan memasuki struktur sekolah yang lebih besar dan berinteraksi dengan kawan-kawan sebaya yang berasal dari berbagai geografis dan latar belakang etnis. Perubahan besar lain yang biasanya terjadi dari SMA menuju perguruan tinggi adalah berkurangnya kontak dengan orangtua karena adanya keinginan untuk merantau atau menjalani perkuliahan di luar daerah asal individu (Santrock, 2007). Alasan para remaja memilih untuk memasuki perguruan tinggi dan menjalani perkuliahan yang ada di luar daerah diantaranya adalah karena ingin mengasah kemandirian dan mencari pengalaman baru (Widihapsari, 2016).

Hasil penelitian yang dilakukan oleh Suryani dan Ginting (2013) menemukan bahwa terdapat beberapa faktor yang memengaruhi keputusan remaja dalam memilih perguruan tinggi, diantaranya adalah keadaan atau bentuk fisik perguruan tinggi, referensi atau informasi mengenai perguruan tinggi yang didapatkan dari keluarga atau mahasiswa senior, biaya masuk perguruan tinggi, serta akreditasi perguruan tinggi yang biasanya diukur dari peringkat yang diberikan BAN-PT. Apabila dilihat dari peringkat BAN-PT universitas pada tahun 2015/2016, Universitas Udayana merupakan perguruan tinggi terbaik di Bali, Nusa Tenggara Barat (NTB), dan Nusa Tenggara Timur (NTT), serta merupakan universitas negeri terfavorit di Bali sehingga hal ini dapat memengaruhi minat mahasiswa dari luar Bali untuk menjalani perkuliahan di Universitas Udayana (BAN-PT, 2015). Beberapa orang mahasiswa baru Universitas Udayana yang berasal dari luar Pulau Bali juga menyatakan bahwa alasan memilih Universitas Udayana adalah karena Universitas Udayana dianggap sebagai perguruan tinggi negeri terbaik di Bali dan merupakan salah satu universitas dengan fasilitas yang memadai, sehingga mahasiswa yang berasal dari luar Pulau Bali memilih Universitas Udayana sebagai alternatif selain universitas di daerah asal (Widihapsari, 2016). Pertimbangan inilah yang melatarbelakangi penelitian ini dilakukan di Universitas Udayana.

Mahasiswa baru dari luar Pulau Bali yang memutuskan untuk berkuliah di Universitas Udayana akan dihadapkan pada situasi belajar di perguruan tinggi yang berbeda dengan masa SMA, dan sekaligus dihadapkan pada kebudayaan serta kebiasaan baru yang ada di lingkungan perkuliahan. Norma dan budaya yang baru, teman kelompok baru, perubahan pada gaya hidup yang menuntut kemampuan manajemen waktu yang lebih baik dibandingkan pada masa SMA, serta perubahan gaya belajar dari SMA ke perguruan tinggi menyebabkan adanya kebutuhan bagi mahasiswa baru yang merantau untuk menyesuaikan diri dengan lingkungan perkuliahan agar proses perkuliahan dapat berjalan dengan lancar (Salami, 2011). Penyesuaian diri merupakan suatu proses yang mencakup respon mental dan tingkah laku individu sebagai usaha dalam menghadapi stres, frustrasi, dan konflik terhadap tuntutan lingkungan, kemampuan untuk berdamai dengan kekecewaan dan mereduksi tekanan dari kebutuhan individu, atau merupakan pola yang diadaptasi dari perilaku yang sesuai dengan berbagai situasi (Schneiders, 1964).

Idealnya, mahasiswa baru yang merantau memerlukan kemampuan penyesuaian diri yang baik agar dapat menjalani perkuliahan dan mengatasi tantangan yang 
dihadapi pada masa awal perkuliahan. Pada kenyataannya tidak semua mahasiswa baru yang merantau dapat menyesuaikan diri dan mengatasi tantangan yang dihadapi dengan mudah, karena perubahan-perubahan dari masa SMA menuju perguruan tinggi dapat menimbulkan berbagai tekanan dan stres sehingga dapat menghambat proses penyesuaian diri mahasiswa baru (Rosiana, 2011). Pernyataan ini didukung dengan hasil wawancara terhadap salah satu mahasiswa baru Universitas Udayana yang berasal dari luar pulau Bali yang berinisial JN juga menceritakan tekanan-tekanan yang dirasakan selama menjadi mahasiswa baru di Universitas Udayana.

Sebagai mahasiswa baru yang merantau, JN mengalami kesulitan dalam mengatur keuangan serta kesulitan membagi waktu untuk kegiatan perkuliahan dan kegiatan penerimaan mahasiswa baru yang diikuti di kampus karena sebelumnya terbiasa meminta bantuan kepada orangtua dan menceritakan semua permasalahannya kepada orangtua. JN juga merasa terbebani oleh kegiatan student day atau kegiatan pengenalan kehidupan kampus di Universitas Udayana karena ada senior yang memarahi mahasiswa baru tanpa alasan yang jelas. Perasaan tertekan yang dialami oleh JN terus berlanjut karena rangkaian kegiatan penerimaan mahasiswa baru masih berjalan hingga bulan Januari tahun 2017, tepat setelah ujian akhir semester dilaksanakan. Sebagai mahasiswa baru, JN diwajibkan mengikuti kegiatan Bakti Ilmiah kepada Masyarakat pada bulan Januari, namun disisi lain, JN memiliki keinginan untuk berlibur di kampung halaman sehingga JN merasa terbebani dan bingung untuk memutuskan mana yang harus diprioritaskan (Widihapsari, 2016).

Mahasiswa lain berinisial LI menyatakan bahwa selama menjadi mahasiswa baru di Universitas Udayana, LI mendapatkan banyak tugas kuliah dan tidak memiliki teman untuk berbagi permasalahan yang dihadapi sehingga LI merasakan homesick (Widihapsari, 2016). Mahasiswa lain berinisial TF juga menceritakan kesulitannya selama menjalani perkuliahan sebagai mahasiswa baru. TF terbiasa dibantu dalam mengerjakan pekerjaan rumah seperti memasak dan mencuci, tetapi pada saat kuliah, tugas tersebut harus dikerjakan secara mandiri. Tugas-tugas dalam rangka penerimaan mahasiswa baru yang diselenggarakan oleh Universitas Udayana membuat TF merasa bingung dan tertekan karena jumlahnya yang terlalu banyak sehingga TF tidak mengetahui cara membagi waktu agar tugas-tugas yang diberikan bisa diselesaikan dengan tepat waktu. Pekerjaan rumah dan tugas-tugas dalam perkuliahan yang menumpuk dinyatakan menimbulkan rasa stres, sehingga TF pernah menyesali keputusannya untuk melanjutkan kuliah (Widihapsari, 2016).

Mahasiswa baru yang merantau akan mengalami kesulitan untuk menjalani perkuliahan dan mencapai prestasi akademik apabila tidak mampu menyesuaikan diri dan mengatasi tekanan-tekanan yang dihadapi (Santrock, 2007). Agar kemampuan penyesuaian diri individu dapat berkembang, diperlukan faktor lain yang dapat membantu terjadinya proses penyesuaian diri sehingga individu dapat menjalani perkuliahan dengan baik dan mencapai prestasi yang diinginkan secara optimal. Seorang mahasiswa baru Universitas Udayana berinisial SY menyatakan bahwa sebagai mahasiswa baru yang merantau, SY memerlukan usaha untuk beradaptasi yang lebih besar agar dapat mengatasi tekanan dan beban yang dirasakan.

Mahasiswa perantau berinisial LI dan SA juga menyatakan bahwa perbedaan budaya, kebiasaan, dan bahasa antara daerah asal dan daerah rantauan pada awalnya menimbulkan kebingungan untuk berinteraksi dengan teman sebaya di kelas, namun LI dan SA mencoba untuk memahami dan menyesuaikan diri dengan budaya, bahasa dan kebiasaan teman di kelas yang mayoritas berasal dari Bali. Mahasiswa baru yang berasal dari luar Pulau Bali juga disarankan untuk tetap menghormati kebudayaan teman sebaya yang mayoritas berasal dari Bali, serta mampu memilah perilaku serta perkataan yang dianggap sesuai dan tidak sesuai dengan kebiasaan teman sebaya, dengan tujuan untuk menjaga perasaan teman sebaya agar tidak terjadi konflik yang dapat mengganggu proses adaptasi di lingkungan perkuliahan. LI dan SA juga menyatakan bahwa mahasiswa baru yang berasal dari luar Pulau Bali dapat mereduksi tekanan yang dirasakan selama menjalani perkuliahan dengan cara berbagi cerita dengan teman, serta menghibur diri sendiri melalui beberapa kegiatan seperti berjalan-jalan atau menonton film (Widihapsari, 2016).

Kemampuan untuk memahami dan menjaga perasaan orang lain, serta kemampuan untuk mengelola emosi diri sendiri seperti yang disebutkan oleh subjek wawancara merupakan bagian dari aspek kecerdasan emosional yang diperkenalkan oleh Goleman (1995). Individu yang cerdas secara emosional akan memiliki kemampuan membina hubungan yang baik dengan orang lain karena terdapat kemampuan untuk mengkomunikasikan perasaan kepada orang lain dan kemampuan untuk mengontrol emosi. Individu yang cerdas secara emosional juga dinyatakan mampu untuk mengelola emosi diri dan mampu untuk menahan tekanan yang ada dalam hidupnya. Mahasiswa baru yang merantau akan menyesuaikan diri dengan mudah apabila termasuk dalam kategori cerdas secara emosional.

Hasil penelitian yang dilakukan oleh Karmiana (2016) menunjukkan bahwa terdapat hubungan positif yang signifikan antara kecerdasan emosional dengan penyesuaian diri pada mahasiswa perantau asal Lampung. Individu dengan kecerdasan emosional yang matang dinyatakan memiliki kontrol diri yang baik, mampu mengekspresikan emosinya dengan tepat atau sesuai dengan keadaan yang dihadapinya, sehingga lebih mampu beradaptasi karena dapat menerima 
beragam orang dan situasi serta mampu memberikan reaksi yang tepat sesuai dengan tuntutan yang dihadapi. Mahasiswa yang merantau disarankan untuk mengembangkan kecerdasan emosional selain hanya memenuhi tuntutan untuk belajar, dengan tujuan meningkatkan kemampuan bekerjasama untuk menciptakan hubungan interpersonal yang baik, serta dapat menyelaraskan dirinya dengan masyarakat sekitar dan lingkungan barunya.

Hasil penelitian lainnya menunjukkan bahwa remaja yang mengalami kesulitan dalam hal pengaturan reaksi emosi atau yang memiliki perilaku impulsif, secara temperamen akan mengalami reaksi yang cukup tinggi terhadap suatu permasalahan dan tidak memiliki ketrampilan emosi yang baik, sehingga seringkali akan merasakan pengalaman yang menyulitkan dalam hal adaptasi di sekolah, pekerjaan, dan lingkungan sosial. Sebaliknya, remaja yang mampu mengatur emosi dan memiliki keterampilan emosi yang baik akan lebih mudah dalam melakukan penyesuaian diri atau adaptasi di lingkungan sekolah (Ni'matuzzakiyah, 2013).

Faktor kunci lain dalam proses penyesuaian diri mahasiswa yang memutuskan untuk merantau adalah dukungan keluarga, baik secara finansial maupun emosional. Keputusan apakah seseorang dapat menyesuaikan diri dan menyelesaikan kuliah atau tidak bergantung pada dukungan sosial, bukan hanya sekedar bergantung pada motivasi dan bakat akademis yang dimiliki mahasiswa (Papalia, dkk, 2008). Pernyataan ini sesuai dengan hasil wawancara yang telah dilakukan dengan mahasiswa baru Universitas Udayana yang berasal dari luar Pulau Bali. Terlepas dari permasalahan yang dihadapi sebagai mahasiswa baru, terdapat beberapa faktor yang menyebabkan mahasiswa perantau masih tetap bertahan untuk mengikuti perkuliahan di Universitas Udayana. Mahasiswa perantau berinisial SY menyatakan bahwa ketika merasa kesulitan dan homesick, SY akan melihat foto keluarga yang dipajang di kamarnya, dan mengingat kembali tujuannya berkuliah adalah untuk membanggakan orangtua (Widihapsari, 2016).

Hasil wawancara terhadap semua subjek juga memberikan kesimpulan bahwa dukungan dari keluarga, saudara yang sudah melewati masa perkuliahan, serta teman sebaya merupakan hal penting untuk membantu mengatasi tekanan yang dialami serta memudahkan proses penyesuaian diri yang dilakukan (Widihapsari, 2016).

Menurut Uchino (dalam Sarafino \& Smith, 2011), dukungan sosial merupakan suatu kenyamanan, kepedulian, penghargaan, atau bantuan yang tersedia bagi individu yang diberikan oleh orang lain atau kelompok tertentu. Hasil penelitian dari Nashriyah, Yusuf, dan Karyanta (2014) menunjukkan bahwa mahasiswa yang menerima dukungan sosial dari orangtua dan keluarga akan lebih percaya dan mampu menghargai kemampuan yang dimiliki sehingga akan merasa yakin dalam mengatasi tantangan dalam perkuliahan.
Jika dikaitkan dengan penyesuaian diri pada mahasiswa baru yang merantau di Universitas Udayana, maka mahasiswa perantau yang mendapatkan dukungan sosial pada saat awal memasuki perguruan tinggi akan merasa percaya terhadap kemampuan yang dimiliki serta akan lebih menghargai diri sendiri sehingga proses penyesuaian diri akan berjalan dengan lebih optimal. Dukungan sosial yang diterima oleh mahasiswa baru yang berasal dari luar Pulau Bali dapat berasal dari berbagai pihak, seperti orangtua, dosen, mahasiswa senior, dan teman sebaya. Adanya dukungan sosial dari berbagai pihak akan membantu proses penyesuaian diri di lingkungan kampus sehingga perkuliahan dapat dijalani dengan lebih mudah.

Penelitian yang dilakukan oleh Amrullah (2012) menemukan bahwa terdapat hubungan positif yang sangat signifikan antara dukungan sosial dengan penyesuaian diri, yang berarti semakin tinggi dukungan sosial maka semakin tinggi kemampuan penyesuaian diri yang dimiliki oleh mahasiswa. Dukungan sosial yang tinggi dinyatakan berpengaruh secara positif pada sikap dan perilaku individu, misalnya merasa lebih percaya diri, memiliki banyak teman, ikut dalam kegiatan teman, menghargai orang lain, menjaga persahabatan, sehingga dapat mempermudah bagi individu dalam melakukan penyesuaian diri.

Hasil penelitian lain yang dilakukan oleh Budiyanto (2015) juga menunjukkan bahwa terdapat hubungan antara dukungan sosial dengan penyesuaian diri di lingkungan kampus, yang artinya, semakin tinggi dukungan sosial yang diberikan atau diterima oleh mahasiswa, maka semakin tinggi pula kemampuan penyesuaian diri mahasiswa di lingkungan kampus. Dukungan sosial yang diterima dinyatakan dapat menyebabkan mahasiswa memiliki keterikatan yang tinggi terhadap institusi serta semakin menumbuhkan komitmen untuk terus berkuliah dan mendapatkan gelar dari institusi perkuliahan. Budiyanto juga menemukan bahwa bentuk dukungan sosial yang paling dibutuhkan oleh mahasiswa untuk bisa menyesuaikan diri di lingkungan kampus adalah kesediaan orang-orang di lingkungan sekitar mahasiwa untuk membuat mahasiswa merasa menjadi bagian dari institusi dan merasa nyaman di kampus sehingga semakin merasa terikat dan berkomitmen terhadap institusi.

Berdasarkan uraian di atas, penelitian ini dilakukan untuk mengetahui apakah kecerdasan emosional dan dukungan sosial berperan terhadap penyesuaian diri mahasiswa baru Universitas Udayana yang berasal dari luar Pulau Bali.

\section{METODE PENELITIAN}

\section{Variabel dan Definisi Operasional}

Variabel tergantung dalam penelitian ini adalah penyesuaian diri serta variabel bebas dalam penelitian ini adalah kecerdasan emosional dan dukungan sosial. Definisi 
operasional dari masing-masing variabel penelitian adalah sebagai berikut:

\section{Penyesuaian Diri}

Penyesuaian diri adalah suatu usaha yang dilakukan individu secara kontinyu, yang mencakup respon mental dan tingkah laku individu sebagai usaha dalam mengelola dan mengatasi tuntutan serta tantangan yang ada sehingga tercapai harmoni atau keselarasan dalam kehidupan sehari-hari. Taraf penyesuaian diri diukur menggunakan skala penyesuaian diri. Semakin tinggi skor yang diperoleh, maka semakin tinggi taraf penyesuaian diri yang dimiliki subjek.

\section{Kecerdasan Emosional}

Kecerdasan emosional adalah suatu kemampuan yang dimiliki individu untuk merasakan, memahami, dan mengekspresikan emosi diri sendiri, mengenali dan memahami emosi orang lain dengan tepat, sehingga dapat menjalin hubungan yang baik dengan diri sendiri dan orang lain dalam kehidupan sehari-hari. Taraf kecerdasan emosional diukur menggunakan skala kecerdasan emosional. Semakin tinggi skor yang diperoleh, maka semakin tinggi taraf kecerdasan emosional yang dimiliki subjek.

\section{Dukungan Sosial}

Dukungan sosial adalah bantuan atau tindakan, baik yang berupa informasi, kepedulian, harga diri, dan kenyamanan yang diterima oleh individu yang berasal dari berbagai sumber seperti keluarga, teman sebaya, mahasiswa senior, dan orang-orang terdekat lainnya. Taraf dukungan sosial diukur menggunakan skala dukungan sosial. Semakin tinggi skor yang diperoleh, maka semakin tinggi taraf dukungan sosial yang dimiliki subjek.

\section{Responden}

Populasi peneltian ini adalah mahasiswa baru Universitas Udayana yang berjumlah 115 orang. Karakteristik populasi dalam penelitian ini antara lain:

1.Mahasiswa baru di Universitas Udayana. Mahasiswa baru didefinisikan sebagai mahasiswa yang memasuki tahun pertama perkuliahan (Santrock, 2007), yang dalam hal ini merupakan mahasiswa Universitas Udayana angkatan 2016

2. Berasal dari luar Pulau Bali

3. Saat ini tinggal di Bali tanpa didampingi keluarga atau saudara

Teknik pengambilan sampel pada penelitian ini adalah teknik simple random sampling, yaitu teknik untuk memilih sampel penelitian dari suatu populasi yang dilakukan secara acak tanpa memperhatikan strata yang ada dalam populasi, dan dilakukan apabila anggota populasi dianggap homogen (Sugiyono, 2014). Teknik simple random sampling dalam penelitian ini dilakukan untuk menentukan nama-nama fakultas di Universitas Udayana yang akan dijadikan sampel penelitian. Apabila nama-nama fakultas sudah terpilih, maka akan diambil mahasiswa yang sesuai dengan kriteria untuk dijadikan sampel penelitian. Skala yang disebarkan pada proses pengambila data adalah sebanyak 115 skala, namun hanya 112 skala yang diisi dengan lengkap dan dapat dianalisis

\section{Alat Ukur}

Alat ukur penelitian ini menggunakan skala penyesuaian diri, skala kecerdasan emosional, dan skala dukungan sosial. Skala penyesuaian diri disusun oleh peneliti berdasarkan aspek-aspek penyesuaian diri menurut Schneiders (1964), skala kecerdasan emosional disusun oleh peneliti berdasarkan aspek-aspek kecerdasan emosional menurut Goleman (1995), dan skala dukungan sosial juga disusun oleh peneliti berdasarkan aspek-aspek dukungan sosial menurut Haber, (2010).

Skala penyesuaian diri terdiri dari 24 aitem pernyataan, skala kecerdasan emosional terdiri dari 30 aitem pernyataan, dan skala dukungan sosial terdiri dari 34 aitem pernyataan. Skala ini terdiri dari pernyataan positif (favorable) dan pernyataan negatif (unfavorable) dengan empat pilihan jawaban yaitu Sangat Sesuai (SS), Sesuai (S), Tidak Sesuai (TS), dan Sangat Tidak Sesuai (STS).

Menurut Azwar (2014), suatu alat tes dinyatakan memiliki validitas yang baik jika alat tersebut mampu memberikan hasil ukur yang sesuai dengan maksud dilakukannya pengukuran. Pada penelitian ini, uji validitas konstruk dilakukan dengan melihat koefisien korelasi item total sebesar 0,30 (Azwar, 2014). Teknik pengukuran reliabilitas yang digunakan pada penelitian ini adalah Alpha Cronbach dimana konstruk atau variabel dapat dikatakan reliabel jika nilai Alpha Cronbach lebih besar dari 0,60 (Ghozali, 2005).

Penyebaran skala uji coba alat ukur dilaksanakan sebanyak dua kali yaitu pertama pada tanggal 28 November sampai 11 Desember 2016 yang diberikan kepada mahasiswa baru Fakultas Kedokteran Universitas Udayana. Setelah pelaksanaan uji coba skala pertama, skala penyesuaian diri dan skala kecerdasan emosional tidak memenuhi syarat uji validitas dan reliabilitas sehingga dibutuhkan uji coba skala kedua yang dilaksanakan pada tanggal 15 sampai 17 Desember 2016. Skala uji coba kedua diberikan kepada mahasiswa baru Fakultas Ilmu Sosial dan Ilmu Politik serta Fakultas Pariwisata Universitas Udayana.

Hasil uji validitas skala penyesuaian diri menunjukkan nilai koefisien korelasi aitem total yang bergerak dari 0,326 - 0,721. Hasil uji reliabilitas skala penyesuaian diri menunjukkan koefisien Alpha Cronbach sebesar 0,913 yang berarti bahwa skala ini mampu mencerminkan $91,30 \%$ variasi skor murni subjek, sehingga dapat disimpulkan bahwa skala penyesuaian diri layak digunakan sebagai alat ukur untuk mengukur taraf penyesuaian diri subjek. 
Hasil uji validitas skala kecerdasan emosional menunjukkan nilai koefisien korelasi aitem total yang bergerak dari 0,309 - 0,672. Hasil uji reliabilitas skala kecerdasan emosional menunjukkan koefisien Alpha Cronbach sebesar 0,900 yang berarti bahwa skala ini mampu mencerminkan $90,00 \%$ variasi skor murni subjek, sehingga dapat disimpulkan bahwa skala kecerdasan emosional layak digunakan sebagai alat ukur untuk mengukur taraf kecerdasan emosional subjek.

Hasil uji validitas skala dukungan sosial menunjukkan nilai koefisien korelasi aitem total yang bergerak dari 0,330 - 0,696. Hasil uji reliabilitas skala dukungan sosial menunjukkan koefisien Alpha Cronbach sebesar 0,922 yang berarti bahwa skala ini mampu mencerminkan 92,20\% variasi skor murni subjek, sehingga dapat disimpulkan bahwa skala dukungan sosial layak digunakan sebagai alat ukur untuk mengukur taraf dukungan sosial subjek.

\section{Teknik Analisis Data}

Uji hipotesis dilakukan apabila data peneletian telah melewati syarat uji asumsi yaitu uji normalitas, uji linearitas, uji multikolinearitas dan uji heteroskedastisitas. Uji normalitas pada penelitian ini menggunakan uji Kolmogorov Smirnov, uji linearitas dilakukan dengan menggunakan uji Compare Means, uji multikolinearitas dilakukan dengan melihat nilai Variance Inflation Factor (VIF) dan nilai Tolerance dan uji heteroskedastisitas dilakukan dengan menggunaka uji Glesjer. Setelah melakukan uji asumsi, data penelitian dianalisis dengan menggunakan metode analisis regresi berganda untuk menguji hipotesis mayor dan hipotesis minor. Analisis data dilakukan dengan menggunakan bantuan program SPSS 20.0 for Windows.

\section{HASIL PENELITIAN}

\section{Karakteristik Subjek}

Berdasarkan data karakteristik subjek, diperoleh bahwa total subjek berjumlah 112 orang dengan jenis kelamin perempuan sebanyak 66 orang dan laki-laki sebanyak 46 orang. Mayoritas subjek penelitian adalah berusia 18 tahun yaitu sebanyak 66 orang, dan mayoritas berasal dari Fakultas MIPA yaitu sebanyak 47 orang. Subjek penelitian berasal dari 19 daerah di Indonesia, dan mayoritas berasal dari Sumatera Utara yaitu sebanyak 29 orang. Sebanyak 92 orang subjek penelitian belum pernah merantau sebelum menjalani perkuliahan.

\section{Deskripsi Data Penelitian}

Hasil deskripsi penelitian variabel penyesuaian diri, kecerdasan emosional dan dukungan sosial dapat dilihat pada tabel 1 .

\begin{tabular}{|c|c|c|c|c|c|c|c|c|}
\hline Variabel & $\mathrm{N}$ & $\begin{array}{c}\text { Mean } \\
\text { Teoretis }\end{array}$ & $\begin{array}{c}\text { Mean } \\
\text { Empiris }\end{array}$ & $\begin{array}{c}\text { Std. } \\
\text { Deviasi } \\
\text { Teoretis }\end{array}$ & $\begin{array}{c}\text { Std. } \\
\text { Deviasi } \\
\text { Empiris }\end{array}$ & $\begin{array}{l}\text { Sebaran } \\
\text { Teoretis }\end{array}$ & $\begin{array}{l}\text { Sebaran } \\
\text { Empiris }\end{array}$ & Nilai t \\
\hline $\begin{array}{l}\text { Penyesuaian } \\
\text { Diri }\end{array}$ & 112 & 60 & 73,76 & 12 & 6,662 & $24-96$ & $45-87$ & $\begin{array}{c}21,857 \\
(\mathrm{p}=0,000)\end{array}$ \\
\hline $\begin{array}{l}\text { Kecerdasan } \\
\text { Emosional }\end{array}$ & 112 & 75 & 89,22 & 15 & 6,434 & $30-120$ & 74-106 & $\begin{array}{c}23,394 \\
(p=0,000)\end{array}$ \\
\hline $\begin{array}{l}\text { Dukungan } \\
\text { Sosial }\end{array}$ & 112 & 85 & 109,96 & 17 & 9,664 & $34-136$ & $86-135$ & $\begin{array}{c}27,339 \\
(\mathrm{p}=0,000)\end{array}$ \\
\hline
\end{tabular}

Hasil deskripsi statistik data penelitian pada tabel 1 menunjukkan bahwa variabel penyesuaian diri memiliki mean teoretis sebesar 60 dan mean empiris sebesar 68,38 dengan perbedaan sebesar 3,38. Hal ini menandakan subjek penelitian memiliki taraf penyesuaian diri yang tinggi karena nilai mean empiris lebih besar daripada mean teoretis $(73,76>60)$. Berdasarkan penyebaran frekuensi, subjek dalam penelitian ini menghasilkan rentang skor antara 45 sampai dengan 87, serta 99,1\% subjek memiliki skor diatas mean teoretis.

Hasil deskripsi statistik data penelitian pada tabel 1 menunjukkan bahwa variabel kecerdasan emosional memiliki memiliki mean teoretis sebesar 75 dan mean empiris sebesar 89,22 dengan perbedaan sebesar 14,22. Hal ini menandakan subjek penelitian memiliki taraf kecerdasan emosional yang tinggi karena nilai mean empiris lebih besar daripada mean teoretis $(89,22>75)$. Berdasarkan penyebaran frekuensi, subjek dalam penelitian ini menghasilkan rentang skor antara 74 sampai dengan 106, serta 100\% subjek memiliki skor diatas mean teoretis.

Hasil deskripsi statistik data penelitian pada tabel 1 menunjukkan bahwa variabel dukungan sosial memiliki memiliki mean teoretis sebesar 85 dan mean empiris sebesar 109,96 dengan perbedaan sebesar 24,96. Hal ini menandakan subjek penelitian memiliki taraf dukungan sosial yang tinggi karena nilai mean empiris lebih besar daripada mean teoretis $(109,96>85)$. Berdasarkan penyebaran frekuensi, subjek dalam penelitian ini menghasilkan rentang skor antara 86 sampai dengan 135 , serta $100 \%$ subjek memiliki skor diatas mean teoretis

\section{Uji Asumsi}

Tabel 2.

Uji Normalitas Data Penelitian

\begin{tabular}{lcc}
\multicolumn{1}{c}{ Variabel } & Kolmogorov-Smirnov & Asymp. Sig (2-tailed) \\
\hline Penyesuaian Diri & 0,882 & 0,417 \\
Kecerdasan Emosional & 0,692 & 0,724 \\
Dukungan Sosial & 0,788 & 0,563 \\
\hline
\end{tabular}

Dukungan Sosial

Uji normalitas dilakukan dengan analisis Kolmogorov Smirnov dimana suatu sebaran data dapat dikatakan normal jika nilai signifikansi (p) > 0,05 (Ghozali, 2005). Tabel 2 menunjukkan bahwa data variabel penyesuaian diri berdistribusi normal dengan nilai Kolmogorov-Smirnov sebesar 0,882 dengan signifikansi sebesar 0,417 ( $\mathrm{p}>0,05)$. Data pada variabel kecerdasan emosional berdistribusi normal dengan nilai Kolmogorov-Smirnov sebesar 0,692 dengan signifikansi $0,724(\mathrm{p}>0,05)$. Data dukungan sosial juga berdistribusi normal dengan nilai Kolmogorov-Smirnov sebesar 0,788 dengan signifikansi 0,563 ( $\mathrm{p}>0,05)$. 
Tabel 3.

Uji Linearitas Data Penelitian

\begin{tabular}{|c|c|c|c|c|}
\hline & & & $\mathbf{F}$ & Sig. \\
\hline Penyesuaian & Between & Linearity & 103,150 & 0,000 \\
\hline $\begin{array}{l}\text { Diri*Kecerdasan } \\
\text { Emosional }\end{array}$ & Group & $\begin{array}{l}\text { Deviation from } \\
\text { Linearity }\end{array}$ & 1,222 & 0,243 \\
\hline Penyesuaian & Between & Linearity & 50,614 & 0,000 \\
\hline Diri*DukunganSosial & Group & $\begin{array}{l}\text { Deviation from } \\
\text { Linearity }\end{array}$ & 1,547 & 0,057 \\
\hline
\end{tabular}

Uji linieritas dilakukan untuk mengetahui apakah hubungan antara variabel bebas dan variabel tergantung menunjukkan garis sejajar atau tidak (Sugiyono, 2014). Langkah kerja untuk melakukan uji linieritas adalah dengan melihat compare mean lalu pada kolom linearity. Hubungan dua variabel dikatakan signifikan linier jika nilai $\mathrm{p}<0,05$. Tabel 3 menunjukkan hubungan yang linear antara penyesuaian diri dan kecerdasan emosional dengan nilai signifikansi $0,000(\mathrm{p}<0,05)$. Hubungan yang linear juga ditunjukkan antara penyesuaian diri dan dukungan sosial dengan nilai signifikansi $0,000(\mathrm{p}<0,05)$. Dapat disimpulkan bahwa terdapat hubungan linear antara penyesuaian diri dengan kecerdasan emosional serta antara penyesuaian diri dengan dukungan sosial.

Tabel 4.

\begin{tabular}{lccl} 
Uji Multikolonieritas Data Penelitian & Tolerance & $\begin{array}{c}\text { Variance } \\
\text { Variabel }\end{array}$ & Keterangan \\
(VIF) & \\
\hline $\begin{array}{l}\text { Kecerdasan } \\
\text { emosional }\end{array}$ & 0,664 & 1,507 & $\begin{array}{l}\text { Tidak terjadi } \\
\text { multikolonieritas } \\
\text { Tidak terjadi } \\
\text { multikolonieritas }\end{array}$ \\
Dukungan sosial & 0,664 & 1,507 &
\end{tabular}

a. Dependent Variabel: Penyesuaian Diri

Uji multikolonieritas digunakan untuk mengetahui apakah terdapat korelasi antara variabel bebas satu dengan variabel bebas lainnya. Model regresi dianggap baik ketika variabel bebas tidak memiliki korelasi yang tinggi dengan variabel bebas lainnya. Hal tersebut dapat dilihat dari nilai VIF kurang dari 10 dan nilai Tolerance yang lebih besar dari 0,1 (Ghozali, 2005). Tabel 4 menunjukkan nilai Tolerance sebesar 0,664 (>0,1) dan nilai VIF sebesar 1,507 $(<10)$, sehingga dapat disimpulkan tidak terjadi multikolonieritas antar variabel bebas yaitu variabel kecerdasan emosional dan dukungan sosial.

\begin{tabular}{l}
$\begin{array}{l}\text { Tabel } 5 \\
\text { Hasil Uji Heteroskedastisitas }\end{array}$ \\
\cline { 1 - 5 } Model
\end{tabular}

Uji heteroskedastisitas bertujuan menguji apakah dalam model regresi terjadi ketidaksamaan varians dari residual satu pengamatan ke pengamatan lain. Pada model regresi yang baik, tidak akan terjadi heteroskedastisitas apabila nilai signifikansinya (p) > 0,05 (Ghozali, 2005). Berdasarkan tabel 5, dapat dilihat nilai signifikansi pada variabel kecerdasan emosional dan dukungan sosial secara berturut-turut adalah 0,053 dan 0,503 ( $\mathrm{p}>0,05$ ). Dapat disimpulkan bahwa tidak terjadi heteroskedastisitas pada model regresi dalam penelitian ini.

Berdasarkan uji normalitas, uji linearitas, uji multikolonieritas, dan uji heteroskedastisitas yang telah dilakukan maka dapat dikatakan data dalam penelitian ini uji asumsi telah dipenuhi sehingga dapat dilanjutkan ke tahap berikutnya yaitu analisis regresi berganda.

\section{Uji Hipotesis}

Hasil uji regresi berganda variabel kecerdasan emosional dan dukungan sosial terhadap penyesuaian diri adalah sebagai berikut:

Tabel 6

Hasil Uji Regresi Berganda Data Penelitian

\begin{tabular}{cccc}
\hline $\mathbf{R}$ & $\mathbf{R}$ Square & Adjusted $\mathbf{R}$ Square & Std. Error of the Estimate \\
\hline 0,705 & 0,497 & 0,488 & 4,767 \\
\hline
\end{tabular}

Pengujian hipotesis mengenai parameter populasi menggunakan informasi dari sampel dan teori probabilitas untuk menentukan apakah hipotesis yang dibuat secara statistik mampu diterima atau ditolak. Hipotesis merupakan suatu jawaban yang bersifat sementara mengenai permasalahan penelitian yang dinyatakan dalam bentuk kalimat pertanyaan (Sugiyono, 2013). Pada penelitian ini, uji hipotesis menggunakan metode analisis regresi berganda dengan bantuan program SPSS 20.0 for Windows. Tabel 6 menunjukkan bahwa koefisien regresi $(\mathrm{R})$ sebesar 0,705 dengan koefisien determinasi (adjusted $\mathrm{R}$ square) sebesar 0,488, yang berarti bahwa kecerdasan emosional dan dukungan sosial secara bersama-sama berperan terhadap penyesuaian diri dengan sumbangan efektif sebesar 48,8\%, sedangkan $51,2 \%$ dipengaruhi oleh faktor lain yang tidak diteliti dalam penelitian ini.

Tabel 7

Hasil Uji Regresi Berganda Signifikansi F

\begin{tabular}{lccccc}
\hline & Sum of Squares & df & Mean Square & F & Sig. \\
\hline Regression & 2449,964 & 2 & 1224,982 & 53,915 & $.000^{b}$ \\
Residual & 2476,527 & 109 & 22,720 & & \\
\hline Total & 4926,491 & 111 & & & \\
\hline a. Dependent Variable: Penyesuaian Diri \\
b. Predictors: (Constant), Kecerdasan Emosional, Dukungan Sosial
\end{tabular}

Tabel 7 menunjukkan bahwa nilai $\mathrm{F}$ hitung adalah sebesar 53,915 dengan taraf signifikansi 0,000 $(<0,05)$ sehingga model regresi dapat digunakan untuk memprediksi penyesuaian diri. Berdasarkan hasil di atas, dapat disimpulkan bahwa kecerdasan emosional dan dukungan sosial secara bersama-sama berperan terhadap penyesuaian diri.

Tabel 8.

Hasil Uji Regresi Berganda Nilai Koefisien Beta dan Nilai T

\begin{tabular}{cccccc}
\hline \multirow{2}{*}{ Model } & \multicolumn{2}{c}{$\begin{array}{c}\text { Unstandardized } \\
\text { Coefficients }\end{array}$} & $\begin{array}{c}\text { Standardized } \\
\text { Coefficients }\end{array}$ & T & Sig. \\
\cline { 2 - 5 } & $\mathrm{B}$ & Std. Error & Beta & & \\
\hline (Constant) & 5,935 & 6,557 & & 0,905 & 0,367 \\
Kecerdasan Emosional & 0,592 & 0,086 & 0,571 & 6,853 & 0,000 \\
Dukungan Sosial & 0,137 & 0,057 & 0,198 & 2,381 & 0,019 \\
\hline
\end{tabular}

Berdasarkan tabel 8 , didapatkan beberapa hasil yaitu sebagai berikut: 


\section{PERAN KECERDASAN EMOSIONAL DAN DUKUNGAN SOSIAL TERHADAP PENYESUAIAN DIRI MAHASISWA BARU UNIVERSITAS UDAYANA YANG BERASAL DARI LUAR PULAU BALI}

1. Nilai koefisien beta terstandarisasi (standardized coefficients beta) pada variabel kecerdasan emosional lebih besar dari nilai koefisien beta terstandarisasi pada variabel dukungan sosial $(0,571>0,198)$. Artinya, kecerdasan emosional memiliki peran yang lebih besar terhadap kemampuan penyesuaian diri subjek dibandingkan dengan dukungan sosial.

2. Nilai T sebesar 6,853 dan nilai signifikansi sebesar $0,000(\mathrm{p}$ $<0,05)$ pada variabel kecerdasan emosional menunjukkan bahwa kecerdasan emosional berperan secara signifikan terhadap penyesuaian diri.

3. Nilai T sebesar 2,381 dan nilai signifikansi sebesar 0,019 (p $<0,05)$ pada variabel dukungan sosial menunjukkan bahwa dukungan sosial berperan secara signifikan terhadap penyesuaian diri.

4. Taraf penyesuaian diri dari masing-masing subjek penelitian dapat diprediksi melalui persamaan garis regresi dengan memasukkan nilai Unstandardized Coefficients B seperti berikut ini:

$$
\begin{aligned}
& \mathrm{Y}=5,935+0,592 \mathrm{X} 1+0,137 \mathrm{X} 2 \\
& \text { Keterangan : } \\
& \mathrm{Y}=\text { Penyesuaian Diri } \\
& \mathrm{X} 1=\text { Kecerdasan Emosional } \\
& \mathrm{X} 2=\text { Dukungan Sosial }
\end{aligned}
$$

\section{Rumus diatas dapat dijelaskan sebagai berikut:}

a. Konstanta sebesar 5,935 menyatakan jika tidak ada penambahan atau peningkatan skor pada kecerdasan emosional maupun dukungan sosial, maka taraf penyesuaian diri yang dihasilkan adalah sebesar 5,935.

b. Koefisien regresi X1 sebesar 0,592 berarti setiap penambahan atau peningkatan satuan skor subjek pada variabel kecerdasan emosional, maka akan terjadi kenaikan taraf penyesuaian diri sebesar 0,592.

c. Koefisien regresi X2 sebesar 0,137 berarti setiap penambahan atau peningkatan satuan skor subjek pada variabel dukungan sosial, maka akan terjadi kenaikan taraf penyesuaian diri sebesar 0,137 .

Berdasarkan hasil uji regresi berganda yang telah

\begin{tabular}{|c|c|c|}
\hline No & Hipotesis & Hasil \\
\hline 1 & $\begin{array}{l}\text { Hipotesis Mayor: } \\
\text { Kecerdasan emosional dan dukungan sosial } \\
\text { berperan terhadap penyesuaian diri mahasiswa } \\
\text { baru Universitas Udayana yang berasal dari luar } \\
\text { Pulau Bali }\end{array}$ & Ha Diterima \\
\hline 2 & $\begin{array}{l}\text { Hipotesis Minor: } \\
\text { a. Kecerdasan emosional berperan terhadap } \\
\text { penyesuaian diri mahasiswa baru } \\
\text { Universitas Udayana yang berasal dari luar } \\
\text { Pulau Bali } \\
\text { b. Dukungan sosial berperan terhadap } \\
\text { penyesuaian diri mahasiswa baru } \\
\text { Universitas Udayana yang berasal dari luar } \\
\text { Pulau Bali }\end{array}$ & Ha Diterima \\
\hline
\end{tabular}
didapatkan, maka rangkuman hipotesis mayor dan minor penelitian ini dapat dilihat pada tabel 9.

Tabel 9.

Rangkuman Hasil Uji Hipotesis Penelitian

\section{Analisis Tambahan}

Tujuan analisis tambahan dalam penelitian ini adalah untuk memperkaya hasil penelitian. Analisis tambahan dilakukan untuk mengetahui apakah terdapat perbedaan taraf penyesuaian diri, kecerdasan emosional dan dukungan sosial apabila dikategorikan berdasarkan jenis kelamin subjek yang dibagi menjadi dua, yaitu laki-laki dan perempuan. Analisis tambahan ini diuji dengan menggunakan independent sample t-test dengan bantuan program SPSS 20.0 for Windows.

Analisis tambahan tidak dapat dilakukan dengan menggunakan karakteristik subjek selain jenis kelamin, karena karakteristik subjek seperti usia, pengalaman merantau, asal fakultas, dan asal daerah tidak memenuhi syarat untuk dilakukan uji komparasi dengan menggunakan independent sample t-test maupun dengan uji anova (untuk karakteristik subjek yang lebih dari dua kategori). Hal ini disebabkan karena jumlah sampel yang akan dibandingkan pada masingmasing karakteristik subjek tidak berada dalam satu kategori yang sama. Uji komparasi hanya dapat dilakukan apabila dua atau lebih sampel yang akan dibandingkan sama-sama dikategorikan sebagai sampel yang berukuran kecil $(\mathrm{N}<30)$ atau sama-sama merupakan sampel yang berukuran besar (N>30) (Sudijono, 2012).

Berdasarkan uji independent sample t-test, dinyatakan terdapat perbedaaan taraf penyesuaian diri, kecerdasan emosional dan dukungan sosial berdasarkan jenis kelamin apabila nilai signifikansi (p) pada tabel $\mathrm{t}<0,05$. Rangkuman hasil uji independent sample t-test pada masingmasing variabel dapat dilihat tabel 10 .

Tabel 10.

Hasil Uji Independent Sample t-Test

\begin{tabular}{lccccc}
\hline & \multicolumn{2}{c}{$\begin{array}{c}\text { Levene's Test for } \\
\text { Equality of Variances }\end{array}$} & \multicolumn{3}{c}{ t-test for Equality of Means } \\
\cline { 2 - 6 } & $\mathrm{F}$ & Sig. & $\mathrm{t}$ & $\mathrm{df}$ & $\begin{array}{c}\text { Sig. } \\
\text { (2-tailed) }\end{array}$ \\
\hline Penyesuaian Diri & .174 & .677 & -.026 & 110 & .979 \\
Kecerdasan Emosional & .062 & .803 & -.365 & 110 & .716 \\
Dukungan Sosial & 1.068 & .304 & -.941 & 110 & .349 \\
\hline
\end{tabular}

Berdasarkan tabel 10, dapat dilihat nilai signifikansi pada tabel Levene's test for equality of variances variabel penyesuaian diri adalah 0,677 ( $p>0,05)$ yang berarti data penyesuaian diri subjek penelitian bersifat homogen, sehingga memenuhi syarat untuk dilakukan uji t-test independen. Nilai signifikansi variabel penyesuaian diri pada kolom t-test for equality of means adalah 0,979 ( $p>0,05$ ), yang berarti tidak terdapat perbedaan taraf penyesuaian diri antara subjek yang berjenis kelamin laki-laki dan perempuan.

Berdasarkan tabel 10, dapat dilihat nilai signifikansi pada tabel Levene's test for equality of variances variabel kecerdasan emosional adalah 0,803 ( $\mathrm{p}>0,05)$ yang berarti data kecerdasan emosional subjek penelitian bersifat homogen, sehingga memenuhi syarat untuk dilakukan uji t-test independen. Nilai signifikansi variabel kecerdasan emosional pada kolom t-test for equality of means adalah 0,716 ( $\mathrm{p}>$ $0,05)$, yang berarti tidak terdapat perbedaan taraf kecerdasan 
emosional antara subjek yang berjenis kelamin laki-laki dan perempuan.

Berdasarkan tabel 10, dapat dilihat nilai signifikansi pada tabel Levene's test for equality of variances variabel dukungan sosial adalah 0,304 ( $\mathrm{p}>0,05)$ yang berarti data penyesuaian diri subjek penelitian bersifat homogen, sehingga memenuhi syarat untuk dilakukan uji t-test independen. Nilai signifikansi variabel dukungan sosial pada kolom t-test for equality of means adalah 0,349 ( $p>0,05$ ), yang berarti tidak terdapat perbedaan taraf dukungan sosial antara subjek yang berjenis kelamin laki-laki dan perempuan.

\section{PEMBAHASAN DAN KESIMPULAN}

Berdasarkan hasil penelitian yang telah didapatkan dan dianalisis dengan menggunakan teknik regresi berganda, dapat diketahui bahwa hipotesis mayor penelitian yaitu kecerdasan emosional dan dukungan sosial berperan terhadap penyesuaian diri mahasiswa baru Universitas Udayana yang berasal dari luar Pulau Bali dapat diterima. Hal ini dapat dilihat dari koefisien $\mathrm{R}$ pada hasil uji regresi adalah sebesar 0,705 dan nilai signifikansi uji $\mathrm{F}$ adalah 0,000 yang menunjukkan bahwa kecerdasan emosional dan dukungan sosial secara bersama-sama berperan terhadap penyesuaian diri. Koefisien determinasi sebesar 0,488 menunjukkan bahwa kedua variabel bebas yaitu kecerdasan emosional dan dukungan sosial memiliki sumbangan efektif sebesar 48,8\% terhadap variabel tergantung yaitu penyesuaian diri. Berdasarkan hasil yang didapatkan, dapat ditarik kesimpulan bahwa kecerdasan emosional dan dukungan sosial menentukan $48,8 \%$ taraf penyesuaian diri yang dimiliki mahasiswa baru Universitas Udayana yang berasal dari luar Pulau Bali. Sebesar 51,2\% lainnya dipengaruhi oleh variabel lain yang tidak dimasukan dalam penelitian ini.

Santrock (2007) menyatakan bahwa faktor kecerdasan emosional seperti kemampuan individu dalam mengelola emosi dan memotivasi diri sendiri, serta faktor dukungan sosial yang diberikan oleh keluarga dan teman sebaya dapat menentukan kemampuan penyesuaian diri yang dimiliki oleh remaja yang menjalani tahun pertama perkuliahan. Individu yang mampu mengelola emosi diri sendiri dan yang mendapat dukungan dari keluarga dan teman sebaya akan memiliki kepercayaan diri dalam menghadapi tuntutan atau tantangan yang dirasakan, serta akan mampu mengatasi kesulitan dengan objektif dan realistis, sehingga akan memudahkan proses penyesuaian diri di lingkungan perkuliahan.

Hipotesis Minor I: Kecerdasan Emosional Berperan terhadap Penyesuaian Diri Mahasiswa Baru Universitas Udayana yang Berasal dari Luar Pulau Bali
Berdasarkan hasil penelitian yang telah dilakukan, dapat diketahui bahwa kecerdasan emosional memiliki peran yang signifikan terhadap penyesuaian diri mahasiswa baru Universitas Udayana yang berasal dari luar pulau Bali. Kecerdasan emosional dapat didefinisikan sebagai kemampuan untuk mengenali, mengevaluasi, mengelola emosi, dan berinteraksi dengan orang lain. Seorang mahasiswa yang cerdas secara emosional akan memiliki kemampuan untuk memilah perilaku dan dapat menyesuaikan perilaku sesuai dengan kelompok atau lingkungan sekitar yang berbeda dengan perilakunya sehari-hari, serta memiliki kemampuan untuk memahami sifat manusia dan memahami perbedaan individu (Goleman, 1995).

Hasil penelitian yang dilakukan oleh Mesidor dan Sly (2016) menunjukkan bahwa mahasiswa internasional yang cerdas secara emosional lebih mungkin untuk berhasil beradaptasi dengan budaya baru, termasuk dengan budaya teman sebaya yang berbeda-beda. Hal ini disebabkan karena mahasiswa yang cerdas secara emosional akan memiliki kemampuan untuk menjalin hubungan yang baik dengan orang lain dan mampu memahami emosi dan perilaku yang ditunjukkan oleh orang lain sehingga akan lebih mudah untuk menerima dan mempelajari kebudayaan baru yang dimiliki teman-temannya, yang pada akhirnya akan mengarah pada proses penyesuaian diri yang berlangsung lebih cepat.

Jazaeri dan Kumar (2008) juga menemukan bahwa kecerdasan emosional secara signifikan berperan terhadap penyesuaian diri mahasiswa terhadap budaya yang berbeda dalam lingkungan perkuliahan. Mahasiswa internasional yang memiliki kecerdasan emosional yang tinggi akan mampu mengelola emosi yang dirasakan sehingga akan mampu mengurangi rasa frustrasi dan mampu mengurangi mekanisme pertahanan diri yang tidak efektif ketika dihadapkan pada permasalahan selama menjalani perkuliahan. Kemampuan untuk mengurangi rasa frustrasi dan mengurangi mekanisme pertahanan diri yang tidak efektif merupakan aspek-aspek dari penyesuaian diri, dan menunjukkan adanya kemampuan penyesuaian diri yang baik.

Hasil penelitian menunjukkan bahwa kecerdasan emosional lebih berperan terhadap penyesuaian diri dibandingkan dengan dukungan sosial, yang ditandai dengan nilai koefisien beta varabel kecerdasan emosional yang lebih tinggi dari nilai koefisien beta variabel dukungan sosial $(0,571$ $>0,198)$. Hal ini menandakan kecerdasan emosional memiliki peran yang signifikan terhadap penyesuaian diri, dan menjadi salah satu faktor yang dapat meningkatkan kemampuan penyesuaian diri mahasiswa baru Universitas Udayana yang berasal dari luar Pulau Bali. Gullekson dan Tucker (2012) juga menemukan bahwa mahasiswa yang mendapat nilai lebih tinggi pada pengukuran kecerdasan emosional memiliki kemampuan penyesuaian diri yang lebih tinggi pula. Penting bagi mahasiswa internasional dari berbagai latar belakang 
budaya untuk menumbuhkan kecerdasan emosional, sehingga pendidik juga dapat didorong untuk menggabungkan kecerdasan emosional dalam pedagogi akademik dalam rangka memfasilitasi penyesuaian budaya mahasiswa internasional.

\section{Hipotesis Minor II: Dukungan Sosial Berperan terhadap Penyesuaian Diri Mahasiswa Baru Universitas Udayana yang Berasal dari Luar Pulau Bali}

Berdasarkan hasil penelitian yang didapatkan, dukungan sosial merupakan faktor lain yang dapat berperan terhadap penyesuaian diri mahasiswa baru Universitas Udayana yang berasal dari luar Pulau Bali. Hasil penelitian ini sejalan dengan penelitian oleh Amrullah (2012) yang menunjukkan semakin tinggi dukungan sosial maka semakin tinggi penyesuaian diri yang dimiliki individu, demikian pula sebaliknya semakin rendah dukungan sosial maka semakin rendah penyesuaian diri yang dimiliki.

Mahasiswa baru yang menerima dukungan sosial tinggi cenderung memiliki ciri-ciri seperti diperhatikan keluarga, diterima di lingkungan, mendapat kasih sayang, mendapat pujian dari orang lain, menerima bantuan, dan mendapat penilaian positif baik dari orangtua, keluarga, teman sebaya, maupun pihak lain di lingkungan kampus (Yusoff \& Othman, 2011). Dukungan sosial yang tinggi berpengaruh secara positif pada sikap dan perilaku individu, seperti menjadikan individu merasa lebih percaya diri, memiliki banyak teman, memiliki kemauan untuk terlibat dalam kegiatan teman, menghargai orang lain, serta menjaga persahabatan. Hal ini dapat mempermudah individu dalam melakukan penyesuaian diri di lingkungan atau situasi baru yang penuh dengan tantangan.

Perbedaan sistem pengajaran di perguruan tinggi dengan SMA menuntut adanya penyesuaian diri pada mahasiswa baru. Penyesuaian diri dengan lingkungan akademik dipengaruhi oleh seberapa besar kesanggupan dan keyakinan diri individu untuk mengerjakan tugas dan peran baru sebagai seorang pelajar di pendidikan tinggi. Keyakinan dan kesanggupan individu dalam menjalankan peran sebagai mahasiswa baru, serta keyakinan untuk menyesuaikan diri dengan baik dapat menguat seiring dengan adanya dukungan sosial yang berasal dari berbagai sumber, baik itu keluarga maupun teman sebaya. Kesejahteraan psikologis individu juga dinyatakan meningkat karena adanya perhatian, pengertian, yang akan meningkatkan harga diri, serta memiliki perasaan positif mengenai diri sendiri (Wirawanty, 2009).

Bejerano (2014) menemukan bahwa dukungan dari pengajar, keluarga, dan teman sebaya memiliki peran yang cukup kuat terhadap penyesuaian diri mahasiswa yang memasuki tahun pertama di perguruan tinggi. Individu yang secara langsung menjadi bagian dari universitas, yang dipercayai oleh mahasiswa sebagai representasi dari institusi yang bersangkutan, dan yang secara langsung berhubungan dengan proses belajar mahasiswa memiliki pengaruh yang lebih besar bagi penyesuaian diri mahasiswa dibandingkan dengan keluarga atau orangtua yang tinggal jauh dari lingkungan belajar mahasiswa. Dukungan sosial dari teman sebaya juga dinyatakan dapat meningkatkan kemampuan penyesuaian diri mahasiswa tahun pertama yang berasal dari latar belakang budaya yang berbeda karena kelompok teman sebaya dapat membantu individu memahami norma dalam memasuki perkuliahan dan motivasi individu untuk menjalani perkuliahan.

\section{Pembahasan Deskripsi Statistik dan Kategorisasi Data Variabel Penyesuaian Diri}

Berdasarkan hasil deskripsi statistik dan kategorisasi data variabel penelitian, dapat diketahui bahwa mayoritas kemampuan penyesuaian diri mahasiswa baru Universitas Udayana yang berasal dari luar Pulau Bali tergolong tinggi, yaitu sebanyak 69 orang $(61,6 \%)$. Hal ini mencerminkan bahwa mahasiswa baru Universitas Udayana yang berasal dari luar Pulau Bali sudah mampu melakukan penyesuaian diri.

Hasil studi pendahuluan (preliminary study) penelitian yang dilakukan pada bulan Oktober tahun 2016 menunjukkan bahwa mahasiswa Universitas Udayana angkatan 2016 yang baru menjalani perkuliahan kurang lebih selama dua bulan cenderung mengalami berbagai tekanan dan perasaan terbebani karena belum mampu melakukan penyesuaian diri baik dengan lingkungan perkuliahan maupun dengan kebiasaan serta kebudayaan yang ada di lingkungan sosialnya (Widihapsari, 2016). Proses pengambilan data penelitian disisi lain dilakukan pada pertengahan bulan Desember tahun 2016, tepatnya ketika mahasiswa Universitas Udayana angkatan 2016 sudah menjalani masa perkuliahan selama satu semester dan telah mengalami proses penyesuaian diri yang lebih lama dibandingkan dengan saat studi pendahuluan dilakukan. Hasil analisis data ini menunjukkan bahwa kemampuan penyesuaian diri mahasiswa tergolong tinggi. Berdasarkan data studi awal dan data penelitian pada variabel penyesuaian diri, dapat dilihat bahwa mahasiswa baru Universitas Udayana memerlukan waktu selama kurang lebih tiga bulan untuk melakukan proses adaptasi dengan lingkungan yang baru sehingga didapatkan skor penyesuaian diri yang tinggi (Widihapsari, 2016).

Temuan dalam penelitian ini sejalan dengan hasil penelitian yang dilakukan oleh Wulandari (2016) yang menemukan bahwa dalam waktu kurang lebih selama enam bulan, kemampuan siswa tahun pertama dalam melakukan penyesuaian diri di lingkungan sekolah akan berangsur-angsur berkembang sejalan dengan perkembangan kemandirian dan kecerdasan emosional siswa. Hal ini dapat menyebabkan kemampuan penyesuaian diri siswa setelah enam bulan pertama tergolong tinggi. Apabila dikaitkan dengan hasil 
penelitian, mahasiswa baru Universitas Udayana yang berasal dari luar Pulau Bali sudah melewati enam bulan masa perkuliahan dan rata-rata memiliki kecerdasan emosional yang sudah berkembang dengan baik sehingga kemampuan penyesuaian diri yang dimiliki akan turut berkembang menjadi lebih baik.

Fatimah (2010) menyatakan bahwa faktor internal yang memengaruhi penyesuaian diri individu adalah faktor perkembangan dan kematangan. Respon-respon yang ada dalam diri individu menjadi semakin matang seiring dengan terjadinya proses perkembangan, yang ditandai dengan adanya perkembangan pada keadaan emosional, sosial dan intelektual yang berpengaruh pada kemampuan penyesuaian diri individu setelah enam bulan pertama individu berada dalam situasi atau lingkungan yang baru.

\section{Pembahasan Deskripsi Statistik dan Kategorisasi Data Variabel Kecerdasan Emosional}

Berdasarkan hasil deskripsi statistik dan kategorisasi data variabel penelitian, dapat diketahui bahwa taraf kecerdasan emosional mahasiswa baru Universitas Udayana yang berasal dari luar Pulau Bali mayoritas tergolong tinggi, yaitu sebanyak 81 orang $(72,3 \%)$. Hal ini memiliki arti bahwa mahasiswa baru Universitas Udayana yang berasal dari luar Pulau Bali telah memiliki kemampuan untuk mengenali dan mengelola emosi yang dirasakan, mampu memahami emosi orang lain, mampu untuk memotivasi diri sendiri, dan mampu membina hubungan yang baik dengan orang lain (Goleman, 1995).

Kecerdasan emosional dinyatakan sebagai suatu komponen mendasar yang berangsur-angsur terbentuk ketika mahasiswa perantau menghadapi berbagai persoalan dalam kehidupan sehari-hari, termasuk membina interaksi dengan orang lain dalam berbagai situasi maupun latar belakang budaya yang berbeda. Berbagai persoalan atau kejadian sehari-hari yang dialami membuat individu akan terusmenerus belajar sehingga keterampilan emosional yang dimiliki akan terus berkembang (Karmiana, 2016). Berbagai persoalan terkait kegiatan perkuliahan dan kegiatan penerimaan mahasiswa baru yang dihadapi oleh mahasiswa baru Universitas Udayana yang berasal dari luar Pulau Bali dapat mengasah kemampuan mahasiswa untuk memecahkan masalah, mengelola emosi dalam menghadapi permasalahan, memotivasi diri sendiri untuk menghadapi permasalahan, dan mengembangkan kemampuan menjalin relasi dengan orang lain, sehingga kecerdasan emosional yang dimiliki juga akan semakin berkembang.

Penelitian lain juga menunjukkan bahwa pada periode awal masa remaja, individu biasanya akan cenderung belajar untuk memproses informasi yang negatif secara lebih mendalam, dan melibatkan kemampuan memori dan pengambilan keputusan yang lebih berat. Seiring berjalannya waktu, individu akan belajar untuk memilah informasi dan situasi yang bersifat lebih memuaskan secara emosional, sehingga perhatian dan memori individu cenderung mengarah pada informasi yang dapat mengoptimalkan kemampuan untuk meregulasi emosi. Semakin bertambah usia individu, maka akan semakin banyak pengalaman emosi yang dialami, sehingga semakin besar pula kemampuan untuk mengontrol emosi yang dirasakan sehingga kecerdasan emosional akan meningkat (Wechtler, Koveshnikov, \& Dejoux, 2015).

\section{Pembahasan Deskripsi Statistik dan Kategorisasi Data Variabel Dukungan Sosial}

Hasil deskripsi statistik dan kategorisasi data variabel penelitian menunjukkan bahwa taraf dukungan sosial yang diterima mahasiswa baru Universitas Udayana yang berasal dari luar Pulau Bali mayoritas tergolong sangat tinggi, yaitu sebanyak 57 orang $(50,9 \%)$. Hasil ini menunjukkan bahwa subjek penelitian sudah menerima dukungan sosial yang penuh dari keluarga, teman sebaya, dan pihak lain yang berada di lingkungan kampus, baik itu dukungan yang bersifat instrumental, dukungan informasi, maupun dukungan emosional.

Stanley dan Patricia (2007) menyatakan bahwa terdapat beberapa faktor yang memengaruhi dukungan sosial, diantaranya adalah adanya kebutuhan fisik, kebutuhan sosial, dan kebutuhan psikis dalam diri individu. Kebutuhan fisik dapat berupa kebutuhan sandang dan pangan. Contohnya adalah mahasiswa baru Universitas Udayana yang berasal dari luar Pulau Bali akan memerlukan buku penunjang perkuliahan dan uang untuk kebutuhan hidup selama tinggal di Bali, sehingga hal ini menyebabkan keluarga harus memberikan dukungan instrumental agar mahasiswa dapat mengikuti perkuliahan dengan baik dan lancar.

Kebutuhan sosial yang berupa pergaulan atau penerimaan dari teman sebaya juga dinyatakan dapat memengaruhi dukungan sosial yang diterima individu. Mahasiswa baru yang merantau akan menghadapi budaya, kebiasaan dan situasi lingkungan yang berbeda dari daerah asalnya, sehingga diperlukan teman sebaya yang dapat memberikan informasi dan bantuan (Amrullah, 2012). Selain kebutuhan sosial, kebutuhan psikis yang berupa rasa ingin tahu, rasa aman, perasaan religius, juga tidak mungkin terpenuhi tanpa bantuan orang lain. Terlebih lagi jika individu sedang menghadapi masalah baik ringan maupun berat, maka orang tersebut akan cenderung mencari dukungan sosial dari orang-orang sekitar sehingga dirinya merasa dihargai, diperhatikan dan dicintai (Stanley \& Patricia, 2007).

\section{Pembahasan Analisis Tambahan}

Berdasarkan hasil analisis tambahan dengan menggunakan uji independent sample t-test pada variabel penyesuaian diri diperoleh hasil bahwa tidak terdapat 
perbedaan penyesuaian diri berdasarkan jenis kelamin. Hasil ini didukung dengan temuan penelitian Warsito (2013) yaitu tidak terdapat perbedaan tingkat penyesuaian diri mahasiswa perantau suku Batak ketika ditinjau dari jenis kelamin. Individu yang penyesuaian dirinya baik atau akurat adalah yang mampu bereaksi terhadap lingkungan dengan cara yang matang, efisien, bermanfaat dan memuaskan, serta dapat menyelesaikan kesulitan-kesulitan yang berasal dari dalam diri maupun lingkungannya. Individu yang berjenis kelamin lakilaki atau perempuan memiliki kesempatan yang sama untuk mengembangkan kemampuan bereaksi terhadap lingkungan dengan cara yang matang, efisien, bermanfaat dan memuaskan. Hal ini mendukung hasil penelitian yang menunjukkan bahwa tidak ada perbedaan taraf penyesuaian diri antara individu dengan jenis kelamin laki-laki atau perempuan.

Penelitian yang dilakukan oleh Rueger, Malecki, dan Demaray (2010) juga menunjukkan bahwa tidak terdapat perbedaan penyesuaian diri antara remaja laki-laki dan perempuan. Hal ini disebabkan karena berbagai tekanan dan kondisi penuh stres akibat situasi baru yang menuntut adanya proses penyesuaian diri dirasakan oleh hampir sebagian besar remaja. Untuk mengatasi tekanan yang dirasakan, maka remaja akan cenderung mencari bantuan dari teman sebaya karena pada fase remaja, teman sebaya memiliki peran yang penting dalam membantu pembentukan identitas remaja dan menjadi salah satu faktor yang memengaruhi perkembangan identitas remaja. Persepsi remaja laki-laki dan perempuan terhadap dukungan dan bantuan yang diberikan oleh teman sebaya cenderung sama, baik itu persepsi yang positif maupun persepsi yang negatif. Apabila remaja laki-laki dan perempuan memiliki persepsi yang positif terhadap dukungan yang diberikan teman sebaya, maka akan terjadi proses penyesuaian diri yang lebih baik dan cepat dibandingkan jika remaja memiliki persepsi yang negatif terhadap dukungan yang diberikan. Berdasarkan penjelasan diatas dapat disimpulkan bahwa perbedaan kemampuan penyesuaian diri cenderung diakibatkan oleh adanya persepsi remaja yang berbeda, bukan disebabkan oleh jenis kelamin yang berbeda.

Analisis tambahan dengan menggunakan uji independent sample t-test pada variabel kecerdasan emosional menunjukkan tidak terdapat perbedaan taraf kecerdasan emosional berdasarkan jenis kelamin. Hal ini sejalan dengan hasil penelitian dari Nasir dan Masrur (2010) yang menemukan bahwa tidak terdapat perbedaan yang signifikan antar skor kecerdasan emosional rata-rata antara mahasiswa yang berjenis kelamin laki-laki dan perempuan. Goleman (1995) menyatakan bahwa kecerdasan emosional antara lakilaki dan perempuan cenderung berbeda dalam hal aspek kecerdasan emosional yang menonjol, bukan pada taraf atau skor kecerdasan emosionalnya.
Laki-laki yang memiliki kecerdasan emosional yang tinggi akan matang secara sosial, outgoing dan ceria, tidak rentan terhadap rasa takut, mampu menunjukkan komitmen kepada individu lainnya, memiliki kapasitas untuk mengambil tanggung jawab, dan memiliki pandangan mengenai etika serta simpatik dan peduli dalam menjalin hubungan dengan orang lain. Berbeda dengan laki-laki, perempuan yang memiliki kecerdasan emosional yang baik disisi lain cenderung bersikap tegas dan mengungkapkan perasaan secara langsung, memandang diri sendiri secara positif, serta memiliki arti hidup. Perempuan dengan kecerdasan emosional yang tinggi cenderung outgoing dan suka berteman, mampu untuk mengekspresikan perasaan secara tepat serta mampu untuk beradaptasi terhadap stres dengan baik (Goleman, 1995). Kecenderungan yang berbeda ini tidak selalu mengarah pada perbedaan taraf atau skor kecerdasan emosional yang dimiliki oleh laki-laki dan perempuan. Hasil penelitian lainnya juga menunjukkan bahwa terdapat taraf kecerdasan emosional yang sama pada laki-laki dan perempuan, namun ketika dilihat berdasarkan aspek-aspek kecerdasan emosional, maka perempuan akan lebih menonjol pada kemampuan mengelola emosi diri dan kemampuan mengekspresikan emosi, sedangkan laki-laki lebih menonjol pada kemampuan menjalin hubungan dengan orang lain (Nasrir \& Masrur, 2010).

Analisis tambahan dengan menggunakan uji independent sample t-test pada variabel dukungan sosial menunjukkan tidak terdapat perbedaan dukungan sosial berdasarkan jenis kelamin. Sejalan dengan penelitian yang dilakukan oleh Sasmita (2015) yang menemukan bahwa tidak ada perbedaan dukungan sosial yang diterima oleh remaja laki-laki dan remaja perempuan. Pada dasarnya, dalam menjalin pertemanan remaja menginginkan teman yang memiliki nilai-nilai dan minat yang sama, seperti teman yang dapat dimengerti, menciptakan perasaan aman, dapat diajak berbicara tentang masalah-masalah yang dihadapi, serta dapat diajak untuk membahas hal-hal yang tidak dapat dibicarakan dengan orangtua, keluarga, maupun guru (Hurlock, 1980). Pola pencarian dukungan yang dilakukan oleh remaja laki-laki dan perempuan juga secara umum dapat dinyatakan sama (Santrock, 2007).

Keterbatasan penelitian ini adalah tidak semua mahasiswa baru Universitas Udayana yang berasal dari luar Pulau Bali yang terpilih menjadi subjek dapat ikut terlibat dalam penelitian. Beberapa koordinator program studi tidak bisa dihubungi dan ada yang menyatakan tidak bersedia berpartisipasi dalam penelitian karena pengambilan data penelitian bertepatan dengan ujian akhir semester dan bertepatan dengan persiapan acara bakti ilmiah mahasiswa baru. Keterbatasan lain dalam penelitian ini adalah penelitian ini hanya memberikan data deskriptif mengenai jumlah mahasiswa baru yang sudah pernah merantau dan belum pernah merantau sebelum memasuki perguruan tinggi, dan 
hanya memberikan data deskriptif mengenai rentang usia dan asal daerah subjek penelitian. Penelitian ini belum memberikan data mengenai perbedaan penyesuaian diri, kecerdasan emosional dan dukungan sosial apabila dikategorikan berdasarkan usia, asal daerah, dan pengalaman merantau subjek sebelum memasuki perguruan tinggi.

Setelah melakukan prosedur analisis data penelitian, karya ini telah mencapai tujuan penelitian yaitu mengetahui peran kecerdasan emosional dan dukungan sosial terhadap penyesuaian diri mahasiswa baru Universitas Udayana yang berasal dari luar Pulau Bali. Berdasarkan penelitian yang telah dilakukan, dapat ditarik kesimpulan bahwa kecerdasan emosional dan dukungan sosial secara bersama-sama berperan terhadap penyesuaian diri mahasiswa baru Universitas Udayana yang berasal dari luar Pulau Bali, kecerdasan emosional berperan terhadap penyesuaian diri mahasiswa baru Universitas Udayana yang berasal dari luar Pulau Bali, dukungan sosial berperan terhadap penyesuaian diri mahasiswa baru Universitas Udayana yang berasal dari luar Pulau Bali. Taraf kecerdasan emosional, dukungan sosial dan penyesuaian diri mahasiswa baru Universitas Udayana yang berasal dari luar Pulau Bali tergolong tinggi, serta tidak ada perbedaan taraf penyesuaian diri, kecerdasan emosional dan dukungan sosial antara subjek yang berjenis kelamin laki-laki dan perempuan.

Berdasarkan kesimpulan yang telah dipaparkan, maka peneliti memberikan saran kepada mahasiswa baru Universitas Udayana yang berasal dari luar Pulau Bali agar tetap menyesuaikan diri dengan norma-norma misalnya norma dalam berbicara yang baik dan sopan yang dianut oleh teman sebaya yang mayoritas berasal dari Bali agar diterima oleh teman sebaya sehingga mampu mempertahankan dukungan sosial yang sudah tinggi. Mahasiswa dapat mempertahankan taraf kecerdasan emosional yang sudah tinggi dengan cara belajar mengekspresikan emosi dengan tepat, menyadari emosi yang dirasakan, mengenali dan memahami emosi orang lain, memotivasi diri sendiri ketika menghadapi permasalahan, dan tetap membina hubungan yang baik dengan orang lain di lingkungan sekitar. Mahasiswa juga dapat menjalin relasi yang lebih luas dengan teman sebaya pada saat mengikuti kegiatan kemahasiswaan untuk memperbesar sumber dukungan sosial sehingga dapat mempersingkat proses penyesuaian diri dalam menjalani perkuliahan.

Saran bagi orangtua adalah orangtua dapat memberikan dukungan secara kontinyu, baik dukungan yang bersifat material, nasihat, maupun informasi selama para remaja menjalani masa awal perkuliahan sehingga dapat mempersingkat waktu yang dibutuhkan remaja untuk melakukan penyesuaian diri. Orangtua juga dapat membantu mengasah kecerdasan emosional yang dimiliki oleh mahasiswa baru agar proses penyesuaian diri pada masa awal perkuliahan dapat berjalan dengan lebih optimal. Cara-cara yang dapat dilakukan untuk mengasah kecerdasan emosional antara lain dengan belajar mengenali emosi diri dan mengelola emosi dengan cara yang tepat, menetapkan tujuan perkuliahan yang realistis dan menghadapi tekanan yang dirasakan dengan cara yang objektif, serta belajar memotivasi diri dan meyakini kemampuan yang dimiliki dalam menyelesaikan tantangan dalam perkuliahan.

Saran bagi pihak universitas adalah pihak universitas dapat memberikan dukungan sosial yang berupa informasi kepada mahasiswa baru pada saat kegiatan student day mengenai gambaran proses perkuliahan di Universitas Udayana, kegiatan kemahasiswaan yang harus diikuti selama menjalani perkuliahan, serta mengenai kemampuan dan keterampilan yang diperlukan oleh mahasiswa baru dalam menghadapi tantangan perkuliahan sehingga mahasiswa lebih siap dalam menjalani perkuliahan. Mahasiswa baru yang memasuki tahun pertama perkuliahan akan mengalami proses penyesuaian diri, sehingga disela-sela kegiatan student day pihak universitas dapat menyampaikan materi pembekalan yang dapat mengasah kecerdasan emosional mahasiswa baru, seperti memberikan materi mengenai cara mengenali emosi, mengekspresikan emosi dengan tepat, dan mengelola emosi yang dirasakan selama menjalani perkuliahan agar proses penyesuaian diri menjadi lebih optimal. Pihak universitas juga dapat menyediakan pusat layanan informasi bagi mahasiswa baru yang berasal dari luar Pulau Bali yang menyediakan informasi mengenai tempat ibadah, tempat kos di daerah kampus, maupun informasi lain diluar perkuliahan yang dapat disediakan di himpunan paguyuban mahasiswa luar Bali, maupun di unit kegiatan mahasiswa yang sudah ada

Rekan sebaya dan mahasiswa senior di kampus diharapkan dapat menjalin hubungan yang baik dengan mahasiswa baru yang berasal dari luar Pulau Bali agar taraf dukungan sosial yang tinggi dapat dipertahankan dan proses penyesuaian diri mahasiswa dari luar Bali menjadi lebih cepat.

Bagi peneliti selanjutnya, disarankan agar ketika melakukan pengambilan data yang melibatkan mahasiswa, sebaiknya peneliti mencari tahu jadwal mahasiswa yang akan dijadikan subjek penelitian dari jauh-jauh hari dan menyesuaikan jadwal pengambilan data dengan kegiatan mahasiswa, sehingga semua mahasiswa yang telah ditetapkan menjadi subjek penelitian dapat ikut terlibat dalam penelitian. Sumbangan efektif pada penelitian ini sebesar 48,8\%, sedangkan sisanya sebesar $51,2 \%$ dijelaskan oleh faktor lain. Peneliti selanjutnya yang ingin melakukan penelitian mengenai penyesuaian diri mahasiswa baru yang berasal dari luar Pulau Bali diharapkan untuk menggunakan faktor lain yang mungkin memengaruhi penyesuaian diri dengan cara menambah jumlah variabel bebas penelitian untuk mendapatkan hasil yang lebih luas dan mendalam. Peneliti selanjutnya juga dapat melakukan uji lanjutan dari penelitian ini yang bertujuan untuk memprediksi kemampuan 


\section{PERAN KECERDASAN EMOSIONAL DAN DUKUNGAN SOSIAL TERHADAP PENYESUAIAN DIRI MAHASISWA BARU UNIVERSITAS UDAYANA YANG BERASAL DARI LUAR PULAU BALI}

penyesuaian diri dengan melibatkan faktor pengalaman merantau sebelum memasuki perguruan tinggi, asal daerah, dan usia subjek.

\section{DAFTAR PUSTAKA}

Agustiani, H. (2009). Psikologi perkembangan pendekatan ekologi kaitannya dengan konsep diri dan penyesuaian diri pada remaja. Bandung: Refika Aditama.

Amrullah, N. (2012). Hubungan antara dukungan sosial dengan penyesuaian diri pada mahasiswa baru di fakultas psikologi universitas muhammadiyah surakarta. Naskah Publikasi. Fakultas Psikologi, Universitas Muhammadiyah Surakarta.

Azwar, S. (2014). Reliabilitas dan validitas. Yogyakarta : Pustaka Belajar.

BAN-PT. (2015). BAN-PT universitas terbaik di Indonesia by university rankings. Diunduh dari www.ban-ptuniversitas.com pada tanggal 16 Januari 2017.

Bejerano, A. (2014). An examination of the role of social support, coping strategies, and individual characteristics in students' adaptation to college. Communication Studies Theses, Dissertations, and Student Research, 28.

Budiyanto, E,A, (2015). Hubungan antara dukungan sosial dengan penyesuaian diri di lingkungan kampus pada mahasiswa fakultas psikologi universitas padjadjaran. Jurnal Exa Alifa B.

Calhoun, J.F. \& Acocella, J.R. (1995). Psychology of adjusment and human relationship. New York : Mc Graw Hill, Inc.

Fatimah, E. (2010). Psikologi perkembangan: perkembangan peserta didik. Bandung : CV Pustaka Setia.

Ghozali, I. (2005). Aplikasi analisis multivariate dengan program SPSS. Semarang : Badan Penerbit Universitas Diponegoro.

Goleman, D. (1995). Emotional intelligence. New York : Bantam Books.

Gullekson, N. L., \& Tucker, M. L. (2012). An examination of the relationship between emotional intelligence and intercultural growth for students studying abroad. Journal of the Academy of Business Education, 13.

Haber, D. (2010). Health promotion and aging: practical applications for health professionals (5th ed.). New York : Springer Publishing Company, Inc.

Hurlock, E. B. (1980). Psikologi perkembangan: Suatu pendekatan sepanjang rentang kehidupan, Edisi 5. Jakarta: Erlangga.

Jazaeri, S. A., \& Kumar, S. K. (2008). Emotional intelligence and cultural adjustment among foreign students in India. Psychological Studies, 53 (1).

Karmiana, N. (2016). Hubungan antara kecerdasan emosi dengan penyesuaian diri mahasiswa perantau asal lampung. Naskah Publikasi. Fakultas Psikologi, Universitas Muhammadiyah Surakarta.

Kartono, K. (2006). Psikologi-kamus. Jakarta : RajaGrafindo Persada.

Mesidor, J.K. \& Sly, K.F. (2016). Factors that contribute to the adjustment of international students. Journal of International Students, 6 (1).
Nasir, M. \& Masrur, R. (2010). An exploration of emotional intelligence of the students of IIUI in relation to gender, age, and academic achievement. Bulletin of Education and Research, 32 (1).

Nashriyah, S.Q., Yusuf, M., \& Karyanta, N.A. (2013). Hubungan antara penyesuaian diri, dukungan sosial keluarga dan kematangan karir pada mahasiswa program studi ilmu komunikasi Fisip UNS. Tidak dipublikasikan. Program Studi Psikologi, Fakultas Kedokteran, Universitas Sebelas Maret.

Ni'matuzzakiyah, E. (2013). Pengaruh motivasi berprestasi dan kecerdasan emosi terhadap penyesuaian diri mahasiswa santri keperawatan. Jurnal Ilmu-Ilmu Kesehatan, 9 (1).

Papalia, D.E., Olds, S.W., \& Feldman, R.D. (2008). Human development (10th). New York: McGraw-Hill.

Rosiana, D. (2011). Penyesuaian akademis mahasiswa tingkat pertama. Sosial, Ekonomi, dan Humaniora, 2 (1).

Rozali, Y.A. (2015). Hubungan efikasi diri akademik dan dukungan sosial orangtua dengan penyesuaian diri akademik pada mahasiswa UEU Jakarta. Jurnal Psikologi, 13 (1).

Rueger, S.Y., Malecki, C.K., \& Demaray, M.K. (2010). Relationship between multiple sources of perceived social support and psychological and academic adjustment in early adolescence: comparisons across gender. J. Youth Adolescence, 39.

Sagita, D.D., Erlamsyah, \& Syahniar (2013). Hubungan antara perlakuan orangtua dngan penyesuaian diri siswa di sekolah. Jurnal Ilmiah Konseling, 1 (1).

Salami, S.O. (2011). Psychosocial predictors of adjustment among first year college of education students. US-China Education Review, 8 (2).

Santoso, L. (2006). Hubungan antara kecerdasan emosional dengan penyesuaian diri pada mahasiswa fakultas psikologi angkatan 2004 universitas "X" Bandung. Naskah Skripsi. Fakultas Psikologi, Universitas Kristen Maranatha.

Santrock, J. W. (2007). Child development (11th ed.) (M. Rachmawati \& A. Kuswanti, Trans.). Jakarta : Erlangga.

Sarafino, E.P. \& Smith, T.W. (2011). Health psychology: biopsychosocial interactions (7th ed.). New York: Wiley.

Sasmita, I.A.H.D. (2015). Peran efikasi diri dan dukungan sosial teman sebaya terhadap penyesuaian diri mahasiswa tahun pertama Program Studi Pendidikan Dokter Fakultas Kedokteran Universitas Udayana. Skripsi tidak dipublikasikan. Program Studi Psikologi, Fakultas Kedokteran, Universitas Udayana, Denpasar.

Schneiders, A.A. (1964). Personal adjustment and mental health. New York : Holt, Rinehart and Winston.

Stanley, M., \& Patricia, G.B. (2007). Buku ajar keperawatan gerontik, Edisi 2. Jakarta: EGC.

Sudijono, A. (2012). Pengantar statistik pendidikan. Jakarta : PT RajaGrafindo Persada.

Sugiyono. (2014). Metode penelitian kuantitatif, kualitatif, dan kombinasi (mixed methods). Bandung : Alfabeta.

Suryani, W., \& Ginting, P. (2013). Faktor-faktor yang mempengaruhi keputusan mahasiswa memilih Fakultas Ekonomi Universitas Islam Sumatera Utara Al Munawaroh Medan. Modernisasi, 9 (1). 
Tim Penyusun Kamus Pusat Bahasa. (2008). Kamus bahasa indonesia. Jakarta : Pusat Bahasa Departemen Pendidikan Nasional Jakarta.

Warsito, H. (2013). Perbedaan tingkat kemandirian dan penyesuaian diri mahasiswa perantauan suku batak ditinjau dari jenis kelamin. Character, 01 (2).

Wechtler, H., Koveshnikov, A., \& Dejoux, C. (2015). Just like a fine wine? Age, emotional intelligence, and cross-cultural adjustment. International Business Review, 24.

Widihapsari, I.A.G.K. (2016). Preliminary study: Permasalahan yang dialami oleh mahasiswa baru Universitas Udayana yang berasal dari luar pulau Bali. Tidak dipublikasikan.

Wijaya, I.P, \& Pratitis, N.T. (2012). Efikasi diri akademik, dukungan sosial orangtua dan penyesuaian diri mahasiswa dalam perkuliahan. Jurnal Persona.

Wirawanty, M.F. (2009). Hubungan antara self efficacy akademik dan dukungan sosial dengan penyesuaian diri mahasiswa pada tahun pertama di Universitas Surabaya. Thesis tidak dipublikasikan. Universitas Surabaya, Surabaya.

Wu, H., Garza, E., \& Guzman, N. (2015). International student's challenge and adjustment to college. Education Research International.

Wulandari, N.K. (2016). Peran kemandirian dan kecerdasan emosional terhadap penyesuaian diri siswa asrama tahun pertama SMK Kesehatan Bali Medika Denpasar. Skripsi tidak dipublikasikan. Program Studi Psikologi, Fakultas Kedokteran Universitas Udayana, Denpasar.

Yusoff, Y.M., \& Othman, A.K. (2011). An early study on perceived social support and psychological adjustment among international students: the case of a higher learning institution in malaysia. International Journal of Business and Society, 12 (2). 